\title{
Innovative Complex Formulation as Topical Treatment for Oral Health Improvment in Periodontal Disease
}

\author{
CORINA MARILENA CRISTACHE ${ }^{1,2}$, EUGENIA EFTIMIE TOTU3*, GABRIELA TANASE ${ }^{4}$, AURELIA CRISTINA NECHIFOR ${ }^{3}$, \\ DANIEL PETRE ${ }^{3}$, MIHAI BURLIBASA ${ }^{1}$ \\ ${ }^{1}$ Carol Davila University of Medicine and Pharmacy, Faculty of Midwifery and Medical Assisting (FMAM), Department of Dental \\ Techniques, 8 Eroilor Sanitari Bvd., 050474, Bucharest, Romania \\ ${ }^{2}$ Concordia Dent Clinic, 7D-7E Vitan-Barzesti Str., Bucharest, Romania \\ 3University Politehnica of Bucharest, Faculty of Applied Chemistry and Material Science, 1-5 Polizu Str., 11061, Bucharest, \\ Romania \\ ${ }^{4}$ Carol Davila University of Medicine and Pharmacy, Faculty of Dental Medicine, Department of Dental Implantology, 19 Plevnei \\ Str., Bucharest, Romania
}

\begin{abstract}
A complex formulation for topical treatment, consisting of melatonin, hyaluronic acid, tetracycline, and metronidazole mixture is proposed as periodontal disease adjunctive treatment. In order to follow the structural aspects of the active mixture, spectrophotometric methods: UV-Vis and fluorescence, have been applied. The results obtained complete our previous studies. By adding metronidazole to the mixture composed of: melatonin, hyaluronic acid, and tetracycline, the conjugated effect of the active compounds, combining antimicrobial action with anti-inflammatory and immunomodulatory effect, is expected to significaly improve supportive therapy in moderate forms of periodontitis.
\end{abstract}

Keywords: metronidazole, melatonin, hyaluronic acid, tetracycline, oral health, topical treatment

Periodontal disease is a multifactorial inflammatory disorder determined by the bacterial biofilm and the host immune response; an inappropriate host response to microorganisms and their products causing the majority of periodontal tissue destruction and ultimately teeth loss [1].

The disruption of bacterial biofilm by scaling and root planing together with supportive therapy are considered, according to the principles of evidence based dentistry, the gold standard procedures for treating and preventing recurrence of periodontal disease $[2,3]$.

The adjunctive treatment should focus on the complex bi-directional host-microbial interaction comprising bacterial destruction agents, but also host-modulating therapeutical factors, in order to address periodontitis.

Recently, a significant number of studies paid particular attention to establishing bi-directional links between periodontal health and systemic conditions, leading to the periodontal medicine concept [2]. Several mechanisms, such as bacteraemia, endotoxaemia, and release of inflammatory mediators from periodontal tissues, have been incriminated for the association of periodontal disease to cardiovascular diseases [3], diabetes [4], cancer, chronic kidney diseases, chronic obstructive pulmonary disease, or rheumatoid arthritis [5], among others.

Due to infection nature of the periodontal disease, adjunctive antibacterial therapy is administrated to eliminate or reduce the pathogenic bacteria in deep pockets, root furcation and concavities, areas not accessible to mechanical removal by hand or power-driven instruments [6].

The proteolytic enzymes released by the predominant pathogens involved in periodontitis, Aggregatibacter actinomycetemcomitans, Porphyromonas gingivalis, Prevotella intermedia, Fusobacterium nucleatum, Tannerella forsythia, Eikenella corredens, and Treponema denticola, cause hosttissue destruction resulting in gingival inflammation, loss of gingival attachment, periodontal pocket formation, alveolar bone resorption and teeth loss $[7,8]$. Once the periodontium is detached from the alveolar bone, and pockets are formed, the lesions become irreversible [8].

In healthy conditions, the multispecies bioûlm, present on all surfaces in the oral cavity, form the resident oral microbiome, which generally exists in harmony with the host, delivering importantbeneûts that contribute to overall health and well-being [9]. Pathological changes may occur within the microbial ecosystem, caused by a change in the relationships between the microbes and the host, with an increased number or acquisition of virulence in the bacterial population, leading to dysbiosis [10].

Due to a great number of side effect from nausea, vomiting, gastrointestinal discomfort, to severe life treating bacterial resistance, the systemic antimicrobial therapy is recommended to be administrated with caution, mainlyin aggressive periodontitis, if the periodontal infection needs to be rapidly suppressed, or in patients with uncontrolled diabetes [6].

Local antibiotic treatment has several advantages over the systemic administration, such as narrow effective range distribution, a high level at the treated site with lower level elsewhere, not requiring patient's compliance [11].

Among the antibiotics recommended as an adjunctive treatment for periodontal disease, tetracycline class (Tetracycline, Minocycline, Doxycycline) and metronidazole (MZ) are mostly used [6]. Tetracycline (T) is a bacteriostatic antibiotic with a broad spectrum of activity against both Gram-positive and Gram-negative species but with modest clinical improvements in probing depth reductions compared with scaling and root planing alone [12].

MZ has a broad-spectrum antimicrobial activity against protozoan infections and obligate anaerobic bacteria, 
efficiently inhibiting anaerobic microorganisms (such as $P$. gingivalis, $F$. nucleatum, among others) in the periodontal pockets [13].

However, local antibiotic therapy alone may also cause dysbiosis. Therefore, alternate topical active compounds have been used as adjunctive treatment of chronic periodontitis, such as chlorhexidine (CLX), a bisbiguanide class cationic agent with antimicrobial, bactericidal, or bacteriostatic effects (depending of dosage) and lack of systemic toxicity but with several side effects including extrinsic pigmentation, possible irritation of the mucosa, and taste changes. Nevertheless, a systematic review with the meta-analysis by da Costa and co-workers evidenced lower benefitin probing depth (PD) reduction and negligible effect on clinical attachment level (CAL) gain, by using topical CLX [14].

Beside the antibacterial effect, for reducing inflammatory parameters such as bleeding on probing (BOP) and PD, the use of hyaluronic acid (HA), melatonin (MEL) or the recently combined MEL and HA in a complex active compound, as adjunctive therapy after scaling and root planing (SRP) in periodontal compromise patients, was also considered [15-17].

The present paper will focus on improved local treatment of periodontal disease by using, for the first time, four active components with antibacterial and immunomodulatory properties mixed in a complex compound proposed to be employ as a topical application in periodontal pockets.

The present paper aims to highlight the association between antibacterial therapy and immunomodulators, in periodontal disease, and to evidence the specific behavior and chemical interaction between T, MZ, MEL, HA in a complex compound for topical administration.

\section{Experimental part}

\section{Materials}

All chemicals of high purity have been provided by Sigma-Aldrich, Merck, Germany: $\left(\mathrm{C}_{1} \mathrm{H}_{2} \mathrm{NO}_{1}\right)$ - hyaluronic acid (HA); $\mathrm{N}$-[2-(5-methoxy-1H-indot-3-yl) ethyl] -melatonin (MEL), $\mathrm{C}_{6} \mathrm{H}_{6} \mathrm{~N}_{3} \mathrm{O}_{3}$-1-(2-Hydroxyethyl)-2-methyl-5-nitroimidazol, metronidazole (MZ) and $\mathrm{C}_{2} \mathrm{H}_{2} \mathrm{~N}_{2} \mathrm{O}_{-}-(4 \mathrm{~S}, 4 \mathrm{aS}$, 5aS,6S,12aS)-4-(Dimethyl amino)-3,6, 10, 12, 12a-penta hydroxy-6-methyl-1,11-diox0-1,4,4a, 5, 5a, 6, 11,12aoctahydrotetracen-2-carboxamid-tetracycline ( $T$ ) (SigmaAldrich, Merck, Germany). There were also used organic solvents as: ethanol and ethanol (Merck KGaA, Darmstadt, Germany). The water used was deionized $(0.158 \mu \mathrm{S} / \mathrm{cm})$.

The method applied for formulation mixture preparation

The formulation mixture complies with the safe posology of each compound [6,18-21]: MEL - 3mg, MZ - 3 $\mathrm{mg}, \mathrm{T}-3 \mathrm{mg}$ and $\mathrm{HA}-100 \mathrm{mg}$ [OSIM patent pending].

The mixtures have been prepared and ultrasonicated for homogenization. All prepared solutions were maintained in cool $\left(8^{\circ} \mathrm{C}\right)$ and dark conditions. The sequential procedure applied to obtain the formulation mixture supposed to dissolve the melatonin, metronidazole, and tetracycline. Then, after their homogenization, the necessary amount of hyaluronic acid was gradually introduced under continuous ultrasonication at room temperature.

\section{Investigation methods}

The applied investigation methods were spectrophotometric, namely FT-IR analysis (Brucker Tensor 27 with ATR device and using OPUS NT 7.0 software), UVVis analysis (UV-Vis spectrophotometer Varian Cary ${ }^{\circledR} 50$ ) and fluorescence determinations (Perkin Elmer spectrophotometer).
The FT-IR determinations were performed on the solid mixture. The FT-IR spectra against the background spectrum were recorded using $4 \mathrm{~cm}^{-1}$ spectral resolution over a wavenumber range $4000-500 \mathrm{~cm}^{-1}$. Both UV-Vis and fluorescence analysis have been run over $200-800$ $\mathrm{nm}$ wavelength range. The samples were introduced in 10 $\mathrm{mm}$ quartz cells.

The derivative spectrophotometry has been applied [16] for strong evidence of the overlapping signals characteristic for $M E L, T, H A$, and $M Z$. This procedure allowed differentiating the presence of each compound in the analyzed mixture.

The fluorescence spectroscopy supposed initially to establish the best excitation wavelength. If there were no provided information, we used the absorption spectrum to estimate the optimum excitation wavelength. After obtaining the absorption spectra, the maximum absorbance was used as an initial excitation wavelength. The starting wavelength was set with about $30 \mathrm{~nm}$ above the excitation wavelength. Such condition allows avoiding Rayleigh scattering for the emission spectrum. The spectra were recorded up to $800 \mathrm{~nm}$, at slow scan speed (100 nm/ $\mathrm{min})$. The excitation and emission slits were set to $10 \mathrm{~nm}$.

A microscope, Leica DM 3000 LED, equipped with an MC 190 HD camera and fluorescence metal-halide lamp Leica EL6000, allowed the acquisition of fluorescence microscopy images for the complex mixture.

\section{Results and discussions}

\section{UV-Vis spectrophotometry investigations}

The structural studies had as a primary purpose the highlight of possible changes of the absorption characteristic bands of each pharmaceutical component when mixed. Figure 1 shows the metronidazole spectrum. The specific spectra of the other components of the topical treatment mixture were presented in our previous work $[16,17]$. As noticed from the individual spectra, there are overlapping of some absorption maxima for HA and MEL, MEL and T, MZ and MEL.

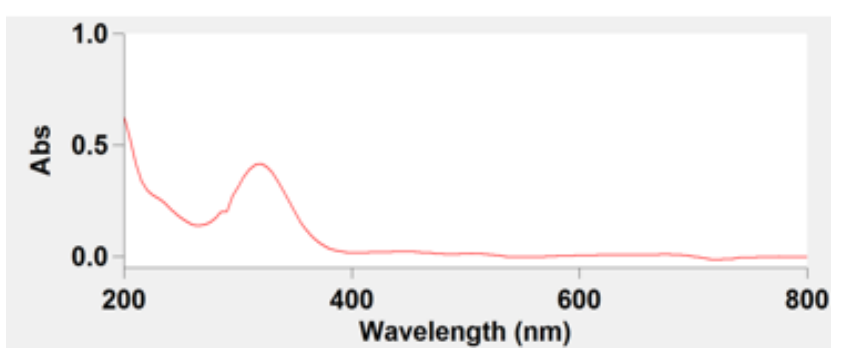

Fig. 1. UV-Vis spectra for metronidazole used to prepare the complex mixture.

In consequence, the usage of the first or second derivate of UV-Vis curve offers the possibility to distinguish the preservation of each component individuality [16].

Figure 2 introduces the UV-Vis spectra of the compound formulation and its second-order derivative calculated. The first order derivate was unable to differentiate the overlapped absorption maxima between the components, and, as a consequence, the $2^{\text {nd }}$ order derivate was considered. The alleviating of the component's maxima intensities is due to the interaction at the level of the functional groups bearing hydrogen that could be involved in hydrogen bond formation. However, the mathematical processing highlighted the presence of individual-specific maxima. 

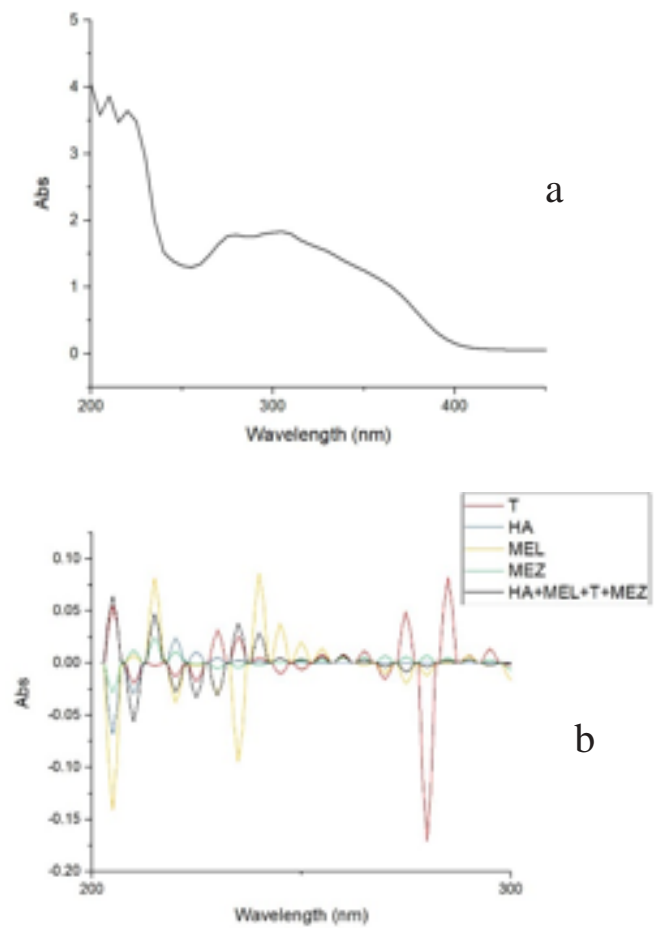

Fig. 2. UV-Vis spectra for the melatonin, hyaluronic acid, metronidazole and tetracycline mixture (a) and the second derivate of UV-Vis spectrum (b).

\section{FT-IR spectrophotometric investigations}

The FT-IR analysis allowed to obtain the mixture - MEL, $H A, M Z$, T spectrum, which has been compared with the individual spectra of each component (MEL, HA, MZ, and T). Figure 3 illustrates the FT-IR spectrum of the complex mixture. This spectrum put in evidence the presence of the major bands for functional groups characteristics of each active component of the studied mixture..

In figure 4 different wavelength ranges from the whole FT-IR spectrum, are presented, to evidence the presence of the specific absorption bands for each compound included in the mixture.

The FT-IR spectrum of the mixture is complex, combining the functional groups' absorption bands characteristic for each pharmaceutical compound [17].

Comparing the overall detailed spectrum - fig. 4, with the individual spectrum of each component, it can be observed that the structural integrity of the active participants - MEL, HA, MZ, and T is preserved. The important absorption bands were identified with the aid of the experimental data from the FT-IR spectra for the MELHA-MZ-T mixture. Table 1 introduces the vibration characteristic of absorption bands. The experimental data presented prove thateach component of the active mixture is preserving its specificity.

Supposing that we have our sample in an excited state, following its irradiation with the appropriate excitation

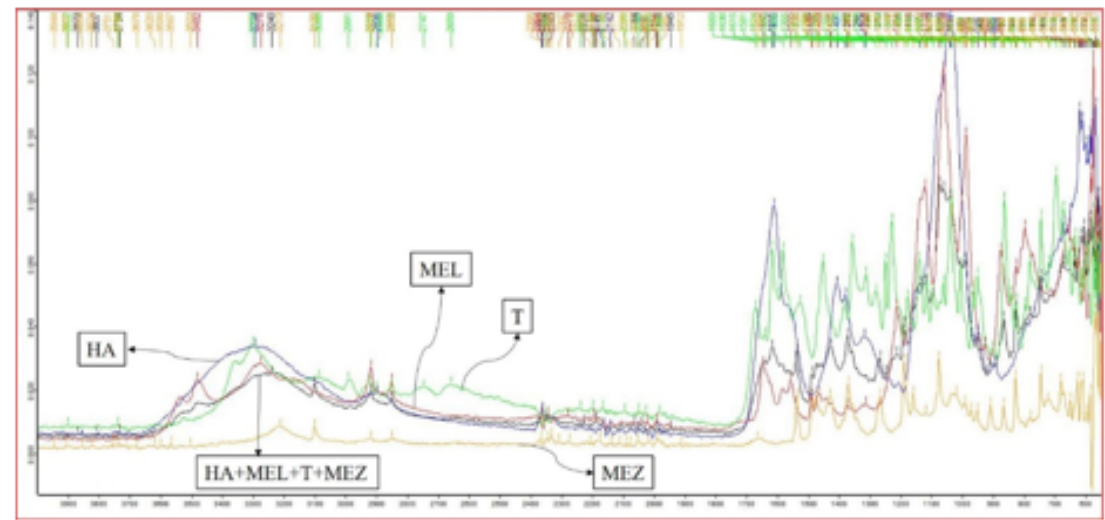

Fig. 3. Complete FT-IR spectrum for the melatonin, hyaluronic acid, metronidazole, and tetracycline mixture

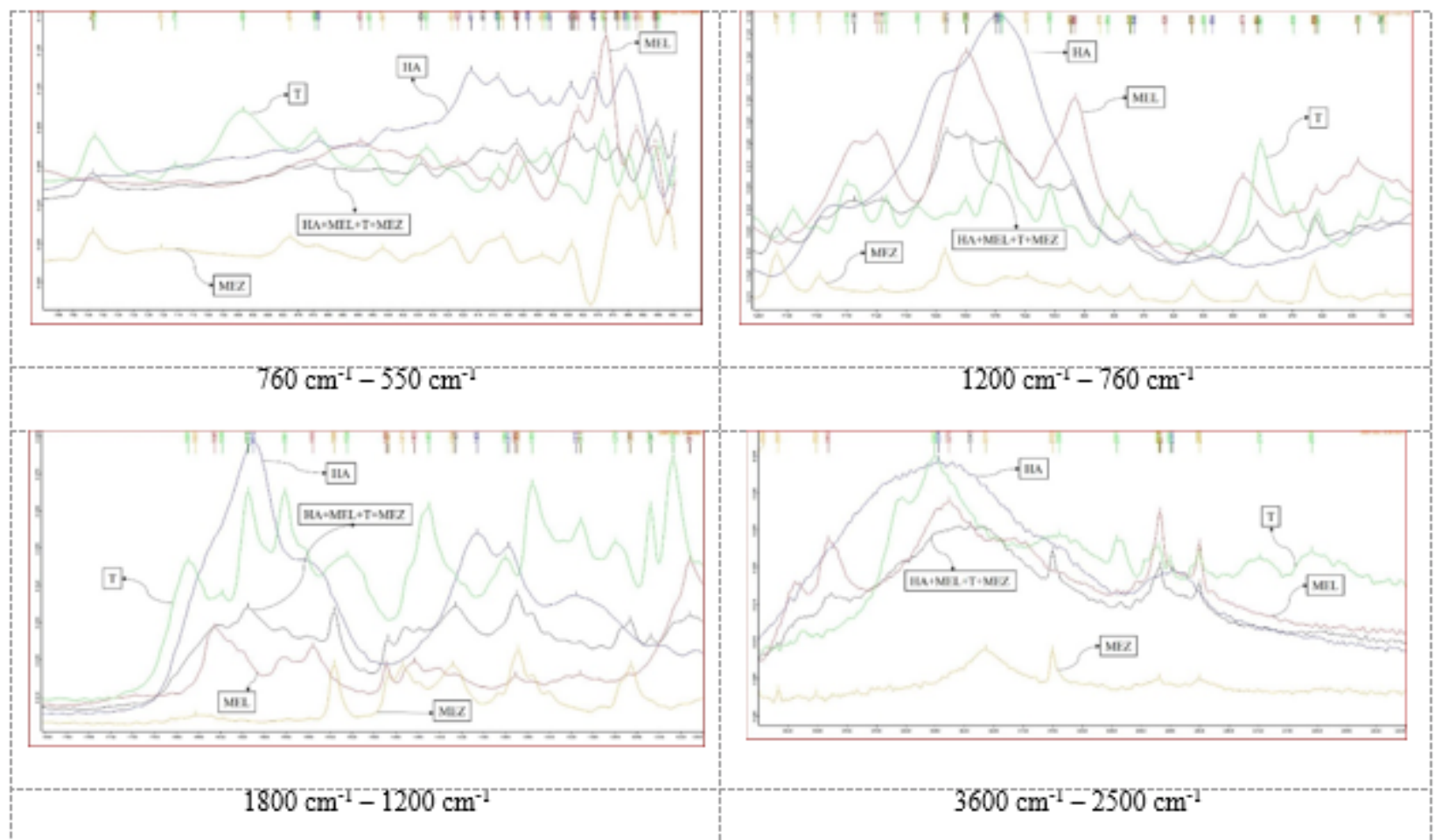

Fig. 4. Details of FT-IR spectrum -covering different wavelength ranges for the melatonin, hyaluronic acid, metronidazole, and tetracycline mixture 


\begin{tabular}{|c|c|c|}
\hline Wavenumber $\left(\mathrm{cm}^{-1}\right)$ & Functional group & Vibration type \\
\hline 3383 & $\mathrm{O}-\mathrm{H}$ & Associated O-H groups (H bonds) \\
\hline 3325 & $\mathrm{O}-\mathrm{H}$ & Associated O-H groups (H bonds) \\
\hline 3108 & $\mathrm{~N}-\mathrm{H}$ & Asymmetric stretching \\
\hline 3049 & $\begin{array}{l}\mathrm{N}-\mathrm{H} \\
\mathrm{C}-\mathrm{H}\end{array}$ & $\begin{array}{l}\text { Symmetric stretching } \\
\text { Aromatic C-H stretching }\end{array}$ \\
\hline 2922 & C-H & Aromatic C-H stretching \\
\hline 2916 & $\mathrm{CH}_{3}$ & Asymmetric stretching \\
\hline 2866 & $\mathrm{CH}_{3}$ & Symmetric stretching \\
\hline $\begin{array}{l}2776 \\
2674\end{array}$ & $\mathrm{C}-\mathrm{H}$ & Methyl group stretching \\
\hline $\begin{array}{l}1743 \\
1666\end{array}$ & $\begin{array}{c}\mathrm{C}=\mathrm{O} \\
\text { Aromatic ring }\end{array}$ & Stretching \\
\hline 1552 & Aromatic ring & Stretching \\
\hline 1452 & $\begin{array}{c}\text { Aromatic ring } \\
\mathrm{CH}_{3}\end{array}$ & $\begin{array}{l}\text { Stretching } \\
\text { Asymmetric bending }\end{array}$ \\
\hline 1358 & $\begin{array}{c}\mathrm{CH}_{3} \\
\text { Terminal geminal dimethyl }\end{array}$ & $\begin{array}{l}\text { Symmetric bending } \\
\text { Bending }\end{array}$ \\
\hline $\begin{array}{l}1234 \\
1178 \\
1159\end{array}$ & $\begin{array}{l}\mathrm{C}-\mathrm{N} \\
\mathrm{C}-\mathrm{C} \\
\mathrm{C}-\mathrm{O}\end{array}$ & $\begin{array}{l}\text { Stretching } \\
\text { Stretching } \\
\text { Stretching }\end{array}$ \\
\hline 1137 & $\mathrm{C}-\mathrm{C}$ & Stretching \\
\hline $\begin{array}{l}1112 \\
1037 \\
1002\end{array}$ & $\begin{array}{l}\text { C-H } \\
\text { C-N } \\
\text { C-O }\end{array}$ & $\begin{array}{l}\text { In-plane Bending } \\
\text { Stretching } \\
\text { Stretching }\end{array}$ \\
\hline 839 & C-N & Stretching \\
\hline $\begin{array}{l}771 \\
678\end{array}$ & Aromatic C-H & Out-plane Bending \\
\hline 641 & $\begin{array}{l}\mathrm{C}-\mathrm{C} \\
\mathrm{C}-\mathrm{H}\end{array}$ & $\begin{array}{l}\text { In-plane Bending } \\
\text { Out-plane Bending }\end{array}$ \\
\hline 567 & $\mathrm{C}-\mathrm{C}$ & Out-plane Bending \\
\hline
\end{tabular}

Table 1

VIBRATION CHARACTERISTIC BANDS FOR THE COMPLEX MIXTURE FT-IR SPECTRUM wavelength, it could give off photon through relaxation phenomenon. Such released photon is characterized through a different wavelength compared to the excitation one. Much more, this wavelength presents a larger value compared to the excitation wavelength. On spectra, this is displaced towards the red region. Figure 5 presents the fluorescence spectra for melatonin at various concentrations between $10^{-5}$ and $8 \times 10^{-5} \mathrm{mg} / \mathrm{mL}$.

The fluorescence spectra recorded for complex formulation and binary mixtures are presented in the figures 6 , and 7.

The fluorescence spectroscopy proved that we could evidence the preservation of the functional and structural characteristics of each compound when they are present in a complex mixture.
The following equation could give the fluorescence intensity:

$$
F=k\left(I_{0}-I\right)
$$

where $k$ represents the fluorescence process' rate constant, $I$ stands for the incident radiation, while $I$ is the intensity thatexists the sample. It results that the difference $\left(I_{0}-I\right)$ represents the quantity of the absorbed radiation.

Lambert-Beer relationship was applied:

$$
A=\varepsilon l c=\log \left(\frac{I_{0}}{l}\right)
$$

where $\varepsilon$ is the absorption coefficient at the exciting wavelength used, I stands for the optical path and $c$ is the sample concentration. After Rreplacing in the previous equation the last relationship, we obtain:

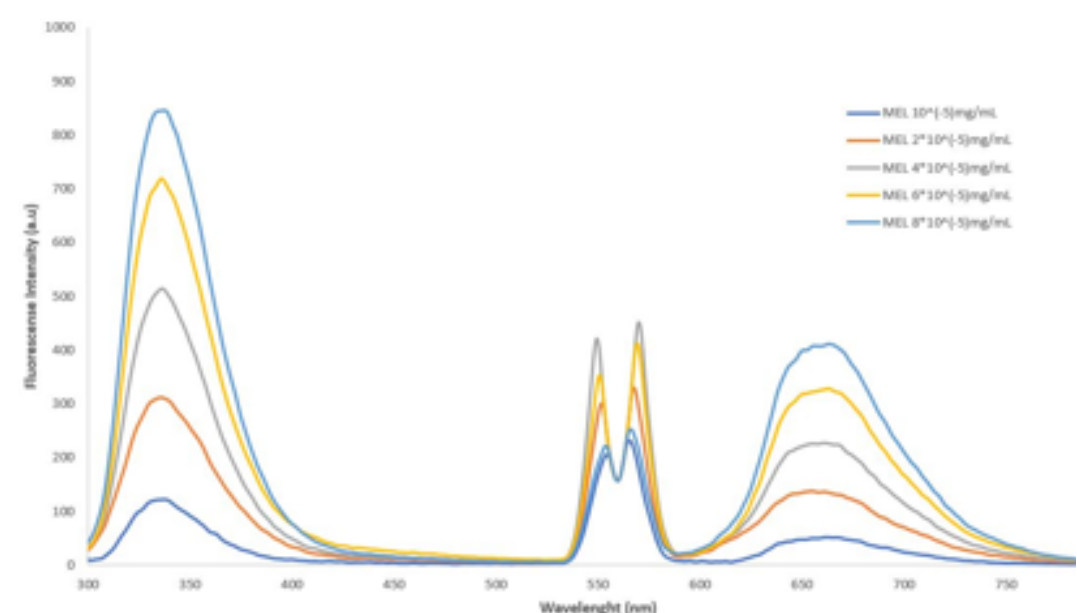

Fig. 5. Fluorescence spectra for the melatonin at various concentrations

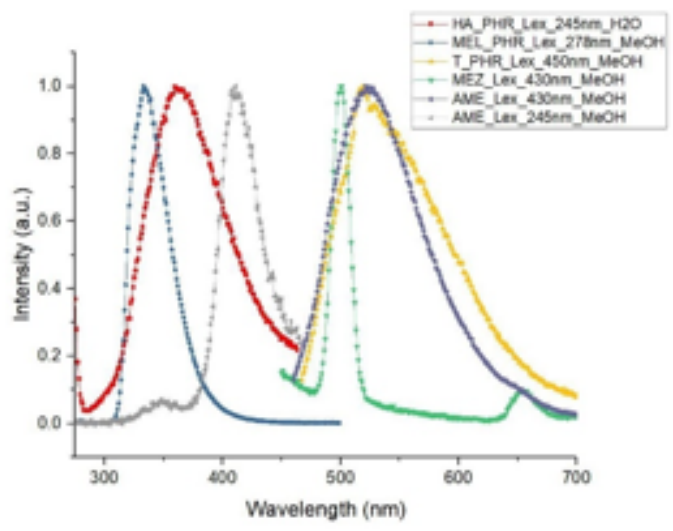

Fig. 6. Fluorescence spectra for the MEL-HA-MZ-T mixture and individual spectrum. 


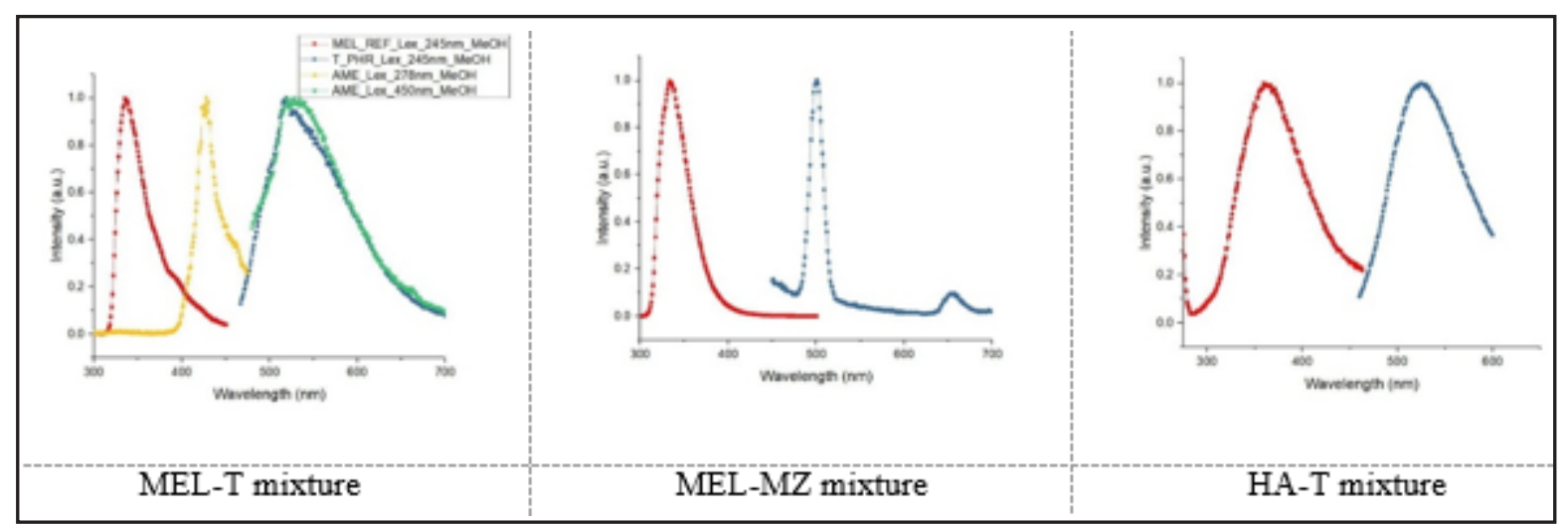

Fig. 7. Fluorescence spectra for various dual mixtures of the active compounds considered.

$$
F=k I_{0}\left(1-10^{-\varepsilon l e}\right)
$$

As noticed from the above relationship, there is an exponential type dependence between the fluorescence intensity and the sample's concentration. Consequently, the fluorescence does not have a linear dependence on concentration. Upon using different mathematical approximations involving a logarithm and factorial development, and considering that the term (2.302 - In $\varepsilon \mid c)$ is less than -0.05 , a linear type dependence of fluorescence for low concentration applies:

$$
F=k I_{0}(2.302-\ln (\epsilon l c))
$$

The last equation could be expressed as simpler as:

$$
F=K l c
$$

Such an equation allows the evaluation of the quantum yield for the studied samples.

Figure 8 introduces the microscopic fluorescence image for the complex mixture containing all four components. The blue glow specific for the melatonin presence could be easily observe.

The main goals of the periodontal therapy are to preserve, improve, and maintain the natural dentition and periodontal tissues in order to achieve health, comfort, esthetics, and function [22]. Although the primary etiologic role of bacteria is well documented, it has become clear, lately, that the tissue destruction seen in periodontitis, can be attributed to dysregulation of inflammatory pathways and inadequate immune responses to the presence of bacteria [23].

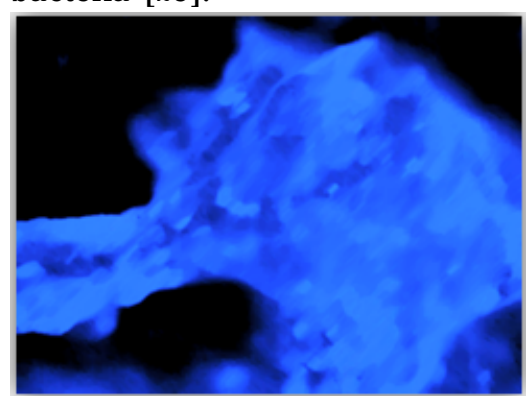

Fig. 8. Fluorescence microscopy image for complex mixture melatonin, metronidazole, and tetracycline in the hyaluronic acid matrix.

A significant number of studies have demonstrated favorable long term outcomes and avoidance of tooth extraction after periodontal treatment if patients practice good oral hygiene and are included in a regular maintenance care program including mechanical debridement and supportive therapy $[23,24]$.

It is widely accepted that SRP leading to mechanical disruption of the plaque biofilm is the primary treatment of choice in periodontal disease based on the consideration of the etiological factors contributing to inflammation and subsequent attachment loss. How ever, mechanical debridement has limitations, mostly regarding the inability to access deep pockets, surface irregularities, and furcation areas, therefore using adjunctive antimicrobial agents, to eradicate or reduce the numbers of pathogenic bacteria, is mandatory [6]. Besides the antibacterial effect, immunomodulatory and anti-inflammatory agents, addressing periodontal tissues, in conjunction with SRP, could significantly improve CAL and lead to PD reduction [15].

The goal of the our work was to associate, in a complex formulation, the antibacterial effect of tetracycline ( $\mathrm{T}$ ) and metronidazole (MZ) with two anti-inflammatory and antioxidant agents, melatonin (MEL), a natural hormone that is generated by the pineal gland, and hyaluronic acid (HA), found mostly in the extracellular matrix of connective tissue.

In order to assess the benefit of the cumulative effect of each active compound of the proposed mixture, the chemical interaction between the components has been investigated.

The rationale for the association of the above-mentioned active compounds was base on the individual effect of topical/systemic administration of each active compound.

Tetracycline ( $T$ ), effective against most spirochaetes, and many anaerobic and facultative bacteria, access bacterial cells by the combined processes of passive diffusion through outer membrane pores and active transfer, utilizing an energy-dependent pump in the inner membrane, and ultimately inhibits protein synthesis on the surfaces of the ribosomes, arresting polypeptide synthesis [25].

Beside its bacteriostatic effect with broad activity against both Gram-positive and Gram-negative species, it was also found to inhibit host-derived collagenolytic matrix metalloproteinases activity, preventing connective tissue destruction, including periodontium, even when administrated in lower dose $[17,26]$.

Metronidazole (MZ), a nitroimidazole compound, primarily developed in France for addressing protozoan infections, enters aerobic and anaerobic bacteria by diffusion and the nitro group of the compound is reduced by nitroreductase (a ferrodoxin-like electron transport protein). At low oxidation-reduction potentials, associated with anaerobic conditions, the reduction precipitates release toxic products such as nitro, nitroso, nitroso-free radicals, and hydroxylamine derivatives, interfering with DNA synthesis and causing disruption of the helical structure of the molecules, leads to death of the involved micro-organisms [27]. Due to this specific action, the antibacterial effect is specific for obligate anaerobic bacteria, usually found in deep periodontal pockets.

$\mathrm{T}$ and $\mathrm{MZ}$ are the most frequently used antimicrobial agents in the management of the periodontal disease; both drugs can be given individually or combined, systemically, 
or applied topically into the periodontal pocket[25]. Topical administration is preferred, ensuring a higher concentration with significantly reduced side effects. MZ was found to be more effective when combined with the T group in the management of refractory and other rapidly progressive forms of periodontitis [28].

The natural hormone Melatonin (MEL) has important antioxidant, anti-inflammatory, anti-angiogenic role, also stimulating bone formation. The administration of MEL or synthetic analogs, in periodontal disease, either as systemic supplement [29] or topical cream [30], after SRP, improved periodontal parameters comparing to SRP alone [15].

Hyaluronic acid (HA), has opposite physiological effects, depending on the molecular weight. The high molecular weight $\mathrm{HA}$ is anti-angiogenic, anti-inflammatory (inhibits endothelial cell growth, binds fibrinogen, reduces the recruitment of inflammatory cells, the levels of inflammatory cytokines and the migration of stem cells) and has a beneficiary role in tissue injury repair, wound healing and immunosuppression. The low molecular weight HA is pro-inflammatory and has pro-angiogenic activities [15,16,31]. However, both high and low molecular HA have bacteriostatic (especially against $S$. aureus and A. actinomycetemcomitans) [32] and fungistatic actions (against C. albicans) [33].

HA has proved beneficiary effects upon local administration for the periodontal disease [34-36].

In our previous papers, we have proposed and analyzed, with promising results, a complex mixtures of MEL and HA $[15,16]$ and also a complex formulation containing MEL, $\mathrm{HA}$ and $\mathrm{T}$ [17]. By including MZ, the active complex mixture will also address the anaerobic group of bacteria, harbored in the deep periodontal pockets, aiming to increase the efficacy of the topical treatment.

\section{Conclusions}

The results obtained by using spectrophotometric methods and fluorescence microscopy for analyzing the proposed complex mixture comprising: tetracycline, metronidazole, melatonin and hyaluronic acid, highlights the conjugated effect of the active compounds, combining antimicrobial action with anti-inflammatory and immunomodulatory effect for improved supportive therapy, in a moderate form of periodontitis. Further, in vivo investigations are needed for assessing the effect on periodontal parameters.

By obtaining new complex pharmaceutical formulations, for local administration, with reduced sideeffects, the paradigm of periodontal therapy may be shifted from a predominantly surgical approach to the greater use of medicinal/pharmacologic strategies, for the benefit of our patients.

Acknowledgments:This work was partially supported by a grant of the Romanian National Authority for Scientific Research and Innovation, CCCDI - UEFISCDI, project number 39/2018 COFUNDMANUNET III-HAMELDENT, within PNCDI III. Authors thank Tiberiu Totu and Roxana Buga for performing the fluorescence microscopy studies.

\section{References}

1.CHAPPLE, I., L., C., MATTHEWS, J., B., Periodontol 2000, 43, no.1, 2007, p.160.

2.MONSARRAT, P., BLAIZOT, A., KEMOUN, P., RAVAUD, P., NABET, C., SIXOU, M., VERGNES, J., N., J Clin Periodontol, 43,no.5, 2016, p.390. 3.SAFFI, M., A., L., FURTADO, M., V., MONTENEGRO, M., M., RIBEIRO, I., W., J., KAMPITS, C., RABELO-SILVA, E., R., POLANCZYK, C., A., ROSING, C., K., HAAS, A., N., Trials, 6, no.14, 2013, p.283.
4.WILLIAMS, R., C., BARNETT, A., H., CLAFFEY, N., DAVIS, M., GADSBY, R., KELLETT, M., LIP, G., Y., THACKRAY, S., Curr Med Res Opin, 24, no.6, 2008, p.1635.

5.LINDEN, G., J., LYONS, A., SCANNAPIECO, F., A., J Clin Periodontol, 40 Suppl no.14, 2013, p.S8.

6.J EPSEN, K., JEPSEN, S. Periodontol, 2000, 71, 2016, p.82.

7.FILOCHE, S., WONG, L., SISSONS, C., H., J Dent Res, 89, no.1, 2010, p.8.

8.ZARCO, M., F., VESS, T., J., GINSBURG, G., S., Oral Dis, 18, no.2, 2012, p.109.

9.MARSH, P., D., ZAURA, E., J Clin Periodontol, 44, Suppl no.18, 2017, p.S12.

10.PARAHITIYAWA, N., B., SCULLY, C., LEUNG, W., K., YAM, W., C., JIN, L., J ., SAMARANAYAKE, L., P., Exploring the oral bacterial flora: Current status and future directions. Oral Dis, 16, no.2, 2010, p.136.

11.MOMBELLI, A., Periodontal Dis, 15, 2012, p.133.

12.BONITO, A., J., LUX, L., LOHR, K., N., J Periodontol, 76, 2005, p.1227.

13.ADHA, N., ERVINA, I., AGUSNAR, H., Int. J. Appl. Dent. Sci, 3, no.2, 2017, p.30.

14.DA COSTA, L., F., N., P., AMARAL, C., D., A., S., F., BARBIRATO, D., D., A., S., LEAO, A., T., T., FOGACCl, M., F., J Am Dent Assoc, 148, no.5, 2017, p.308.

15.CRISTACHE, C., M., TOTU, E., E., CRISTACHE, G., NECHIFOR, A., C., PINTILIE, I., I. Rev. Chim. (Bucharest), 70, no. 3, 2019, p.1089.

16.CRISTACHE, C., M., TOTU, E., E., PETRE, D., BUGA, R., CRISTACHE, G., TOTU, T., Rev. Chim. (Bucharest), 69, no.8, 2018, p.1996.

17.TOTU, E., E., CRISTACHE, C., M., BUGA, R., DUMITRU, F., TOTU, T. Rev. Chim. (Bucharest), 70, no. 5, 2019, p.1551.

18.ANDERSEN, L., P., H., GOGENUR, I., ROSENBERG, J., REITER, R., J., Clin Drug Investig, 36, 2016, p.169.

19.MONTERO, J., LOPEZ-VALVERDE, N., FERRERA, M., J., LOPEZVALVERDE, A., J Clin Exp Dent, 9, no.9, 2017, p.e1081.

20.TASHIRO, T., SEINO, S., SATO, T., MATSUOKA, R., MASUDA, Y., FUKUI, N., Sci World J, 2012, doi:10.1100/2012/167928.

21.GIURGIU, M., C., PAUNICA, S., MANIU, G., DUMITRIU, H., T., DUMITRIU, A., S., Rom Biotechnol Lett, 18, no.4, 2013, p.8551.

22.*** Comprehensive Periodontal Therapy: A Statement by the American Academy of Periodontology, J Periodontol, 82, no.7, 2011, p.943.

23.MOMBELLI, A., Periodontol, 2000, 79, 2019, p.190.

24.AXELSSON, P., NYSTROM, B., LINDHE, J., J Clin Periodontol, 31, no.9, 2004, p.749.

25.SEYMOUR, R., A., HEASMAN, P., A., J Dent, 23, no.1, 1995, p.5.

26.GOLUB, L., M., ELBURKI, M., S., WALKER, C., RYAN, M., SORSA, T., TENENBAUM, H., GOLDBERG, M., WOLFF, M., GU, Y. Int Dent J, 66, no. 3, 2016, p.127.

27.GREENSTEIN, G., J Periodontol, 64, 1993, p.1.

28.CHRISTERSSON, L., A., VAN WINKELHOFF, A., J., ZAMBON, J., J., DE GRAAFF, J., GENCO, R., J., J Dent Res, 68, 1989, p.197.

29.CHITSAZI, M., FARAMARZIE, M., SADIGHI, M., SHIRMOHAMMADI, A., HASHEMZADEH, A., J Dent Res Dent Clin Dent Prospects., 11, no.4, 2017, p.236.

30.CUTANDO, A., LOPEZ-VALVERDE, A., GOMEZ-DE DIEGO, R., DE VICENTE, J., REITER, R., HERRERO FERNANDEZ, M., FERRERA, M., J., Odontology, 102, no.2, 2014, p. 290.

31.SLEVIN, M., KRUPINSKI, J., GAFFNEY, J., MATOU, S., WEST, D., DELISSER, H., SAVANI, R., C., KUMAR, S. Matrix Biol., 26, no. 1, 2007, p. 58

32.PIRNAZAR, P., WOLINSKY, L., NACHNANI, S., HAAKE, S., PILLONI, A., BERNARD, G., W. J. Periodontol. 70, 1999, p. 370.

33.SAKAI, A., AKIFUSA, S., ITANO, N., KIMATA, K., KAWAMURA, T., KOSEKI, T, TAKEHARA, T., NISHIHARA, T. Med. Mycol, 45, no. 1, 2007, p 73.

34.RAJAN, P., BARAMAPPA, R., RAO, N., M., PAVALURI, A., K., RAHAMAN, S., M., J Clin Diagn Res., 8, no.12, 2014, p.ZC11.

35.SAHAYATA, V., N., BHAVSAR, N., V., BRAHMBHATT, N., A., Oral Health Dent. Manag., 13, no.3, 2014, p.779.

36.GONTIYA, G., GALGALI, S., R., J Indian Soc Periodontol., 16, no.2, 2012, p.184. 